\title{
Comparing physical quality of tilled and no-tilled soils in an almond orchard in southern Italy
}

\author{
Mirko Castellini, ${ }^{1}$ Mario Pirastru, ${ }^{1}$ Marcello Niedda, ${ }^{1}$ Domenico Ventrella ${ }^{2}$ \\ ${ }^{1}$ Dipartimento di Agraria, Università di Sassari; ${ }^{2}$ Consiglio per la Ricerca e la Sperimentazione \\ in Agricoltura, Unità di Ricerca per i Sistemi Colturali degli Ambienti caldo-aridi (CRA-SCA), \\ Bari, Italy
}

\begin{abstract}
No-tillage (NT) is an alternative way of reducing costs and lessening the burden of working the land, but in essence it is a method of sustainable land use in dryland cropping systems. The physical quality of the soil is the fundamental factor that defines the sustainability of agro-ecosystems, and its evaluation can be obtained using both capacitive and dynamic indicators. The main objectives of this study were: i) to assess the physical quality of the soil in an almond orchard where long-term different soil tillage systems and weed control methods, such as NT with chemical control and surface tillage (ST), were used; and ii) to compare the indicators under consideration with the proposed reference values, using the information gathered to evaluate the effects of NT and ST. The following physical properties were determined: bulk density, air capacity, macroporosity, plant available water capacity, relative field capacity, Dexter's index, field saturated hydraulic conductivity, as well as the location (modal, median, and mean pore diameter) and shape (standard deviation, skewness, and kurtosis) parameters which corresponded to the equivalent pore size distribution functions. Our results showed that the physical soil indicators adopted were sufficiently sensitive to identify tillage-induced changes and then to quantify the physical quality of rigid to moderately expansive agricultural soils. After thirty years of NT, a set of capacitive indicators, along with measurements of hydraulic conductivity, used in conjunction with an optimal pore volume distribution and the water release curve, unanimously classified the quality of the studied soil as optimal or near optimal.
\end{abstract}

Correspondence: Mirko Castellini, Dipartimento di Agraria, Università di Sassari. E-mail: mcastellini@uniss.it

Key words: hydraulic conductivity, no-tillage, soil physical quality, surface tillage, water retention curve.

Received for publication: 28 May 2013.

Revision received: 23 July 2013.

Accepted for publication: 23 July 2013.

(C) Copyright M. Castellini et al., 2013

Licensee PAGEPress, Italy

Italian Journal of Agronomy 2013; 8:e20

doi:10.4081/ija.2013.e20

This article is distributed under the terms of the Creative Commons Attribution Noncommercial License (by-nc 3.0) which permits any noncommercial use, distribution, and reproduction in any medium, provided the original author(s) and source are credited.

\section{Introduction}

The use of the no-tillage (NT) method of land management has increased worldwide over the past few decades (Kassam et al., 2012). Generally, NT is an alternative way of reducing costs and lessening the burden of working the land, but in essence it is a method of sustainable land use in dryland cropping systems, where it is recommended as a management practice to optimise soil water retention (Shaver et al., 2002). Moreover, it is a useful way of minimising the negative impacts of climate changes (Olesen and Bindi, 2002) and is suggested as a method for improving carbon sequestration in the soil (Lal, 2000).

Several studies have found implementation of NT results in overcompaction of the soil (Tebrügge and Düring, 1999) but in other studies there was no significant soil compaction (Logsdon and Karlen, 2004; Blanco-Canqui et al., 2004). Furthermore, when compared with surface tillage, long-term NT can also significantly improve water retention characteristics or aggregate stability, increasing the connectivity of the pores (Strudley et al., 2008). In other words, when NT is used, soil compaction may still occur, but this does not always have a detrimental effect on crop production (Pelegrin et al., 1990; Unger and Fulton, 1990). In any case, its effects should always be assessed for a specific site, taking into consideration the type of agricultural cultivation and the soil types, as well the particular climatic conditions. For example, Gómez et al. (1999) reported the results of a long-term experiment in an olive orchard submitted to conventional tillage methods and NT in southern Spain. They found that the yield was not affected by tillage, except in one year when precipitation was very low. In that year, yields from NT were significantly higher than those from conventional tillage.

Nonetheless, conventional or minimum tillage are still widely used as soil management practices because producers believe that only these methods ensure higher crop yields.

Evaluation of the physical properties of the soil, obtained from water retention curve [ such as air capacity (AC), macroporosity, plant available water capacity, relative filed capacity, Dexter's index (S)], and also from the dry bulk density of the soil, have provided useful information for assessing the physical quality of the soil, and have confirmed their potential usefulness when comparative studies of soil management are made. For example, in a recent paper, Abu and Abubakar (2013) evaluated the effects on soil hydro-physical properties of four tillage techniques. The Authors highlighted the sensitivity of the physical indicators of the soil that were used in relationship to the modifications caused by different soil tillage methods, and concluded that the soil subjected to conventional tillage had poorer physical quality at all the depths measured. There are also many other examples of similar approaches to agricultural soils to be found in the literature, including those reported by Aparicio and Costa (2007), Cavalieri et al. (2009), Li et al. (2011), Oicha et al. (2010), Reynolds et al. (2007), and Silva et al. (2011). 
Reynolds et al. (2009) have suggested identifying the changes in the physical quality of the soil by comparing the pore volume distribution function of the soil with an optimal reference curve. This provides the corresponding optimal values and the authors claim that the proposed approach may be used to assess the physical quality of the soil.

However, so far the approach proposed by Reynolds et al. (2009) has only been applied in a few cases (Shahab et al., 2013) and further research is needed.

Determining the dynamic physical properties of the soil may be more crucial than determining its physical quality. It is also useful to measure the field saturated hydraulic conductivity since this provides supplementary information which helps us to better understand the complex mechanisms through which management of the soil affects its physical quality.

Several methods may be used to obtain hydraulic properties of the soil at the point scale, both in the laboratory and in the field. For example, the soil of a small field area (i.e. a few $\mathrm{m}^{2}$ ) can physically and hydraulically be characterized by carrying out a few replicated measurements of the variables of interest, using both well-known (Bagarello et al., 2013a) and innovative (Bagarello et al., 2013b) techniques.

Two of the most rigorous methods for obtaining the hydraulic properties of the soil are the instantaneous profile method and the evaporation method. Both of these experimental methods require careful monitoring of both soil water content and soil pressure head. However, they each have different advantages and disadvantages. For example, the former may provide a highly representative evaluation of field conditions but it is cumbersome and time-consuming (Basile et al., 2003). The latter is a very effective and rapid transient laboratory method for simultaneous determination of both $\theta(h)$ and $\mathrm{K}(h)$ relationships and is adequate for modelling purposes (Pirastru and Niedda, 2010, 2013). But its validity depends heavily on the soil volume used for soil hydraulic characterisation being truly representative, and on the accuracy of the measurements taken close to water saturation. Another source of uncertainty may also be related to the use of measurements carried out in the laboratory to explain field conditions (Basile et al., 2003). In 2006, Basile et al. addressed this important issue and proposed a robust scaling procedure for deducing field unsaturated hydraulic properties from laboratory measurements. They pointed out that the general unrestricted applicability of the proposed method.

However, regardless of the method adopted, studies aimed at defining and measuring the physical quality of the soil should make use of soil which is being examined in consistent, long-term field experiments, in order to ensure that quasi-steady soil quality conditions have been reached (Reynolds et al., 2007). Evaluation of the physical quality of the soil also requires comparisons to be made between the measured values and one or more reference values or intervals. For the moment, the optimal values for physical quality of the soil in order to achieve maximum field crop production with minimum environmental degradation remain largely unknown (Reynolds et al., 2007). However, various empirical guideline parameter values have been proposed in the literature (Topp et al., 1997; Dexter, 2004; Dexter and Czyż, 2007; Reynolds et al., 2009).

Thus the main objectives of this study were: i) to consider a longterm experiment to assess the physical quality of the soil of an almond orchard where different soil tillage systems and weed control methods were used, i.e. NT with chemical control and surface tillage; ii) compare Reynolds's indicators with the proposed reference values.

\section{Materials and methods}

\section{Physical quality indicators of the soil: a brief review}

The bulk density $\left(\rho_{b}\right)\left(\mathrm{g} \mathrm{cm}^{-3}\right)$ is defined as the oven-dry soil mass $\left(\mathrm{M}_{\mathrm{s}}, \mathrm{g}\right)$ per unit bulk soil volume $\left(\mathrm{V}_{\mathrm{s}}, \mathrm{cm}^{3}\right)$. This is measured at $h=-100$ $\mathrm{cm}$ (corresponding to a field capacity) to allow for possible soil shrinking or swelling (Reynolds et al., 2009):

$$
\rho_{b=} M_{s} / V_{s}
$$

It is an index of the mechanical resistance to root growth (Topp et al., 1997), but it is often used as in indirect indicator of aeration and the ability to store and transmit water (Reynolds et al., 2009). For soils of medium or fine texture, various authors report that, for maximum crop production, the optimal range for $\rho_{b}$ is $0.9-1.2 \mathrm{~g} \mathrm{~cm}^{-3}$. If $\rho_{b}$ values exceed $1.3 \mathrm{~g} \mathrm{~cm}^{-3}$ then land productivity decreases due to inadequate soil aeration (Reynolds et al., 2009). However, for most agricultural soils, values below $0.9 \mathrm{~g} \mathrm{~cm}^{-3}$ may cause inadequate plant anchoring and a reduction in plant-available water capacity (Reynolds et al., 2009). This does, however, also depend on the specific soil conditions.

The AC $\left(\mathrm{cm}^{3} \mathrm{~cm}^{-3}\right)$, is the ability of the soil to store and transmit air. It is traditionally defined as:

$A C=\theta_{s}-\theta_{F C}$

$\theta_{s}\left(\mathrm{~cm}^{3} \mathrm{~cm}^{-3}\right)$ being is the saturated volumetric water content and $\theta_{F C}\left(\mathrm{~cm}^{3} \mathrm{~cm}^{-3}\right)$ the volumetric water content corresponding to the field capacity at $h=-100 \mathrm{~cm}$ (Reynolds et al., 2002) (-0.33 bar, according to the pressure plate apparatus).

Soil aeration is, therefore, essential for good crop production and overall soil health (Topp et al., 1997). According to Reynolds et al. (2009), a near surface $A C \geq 0.14 \mathrm{~cm}^{3} \mathrm{~cm}^{-3}$ is required in sandy loam or clay soils. However, a more traditional threshold level is typically recommended for agricultural soils $\left(\mathrm{AC}>0.10 \mathrm{~cm}^{3} \mathrm{~cm}^{-3}\right.$ ) in order to reduce the incidence of crop-damage or yield-reducing aeration deficits in the root zone (Reynolds et al., 2009).

The plant-available water capacity (PAWC) $\left(\mathrm{cm}^{3} \mathrm{~cm}^{-3}\right)$ is traditionally defined as:

$$
P A W C=\theta_{F C}-\theta_{P W P}
$$

$\theta_{P W P}\left(\mathrm{~cm}^{3} \mathrm{~cm}^{-3}\right)$ being is the volumetric water content corresponding to permanent wilting point (at $h=-15,300 \mathrm{~cm}$ ). This refers to the soil's ability to store and provide water that is available to plant roots. A $P A W C \geq 0.20 \mathrm{~cm}^{3} \mathrm{~cm}^{-3}$ is generally considered ideal for root growth and functions, while $0.15 \leq P A W C<0.20 \mathrm{~cm}^{3} \mathrm{~cm}^{-3}$ is considered good, $0.10 \leq P A W C<0.15 \mathrm{~cm}^{3} \mathrm{~cm}^{-3}$ is limited, and $P A W C<0.10 \mathrm{~cm}^{3} \mathrm{~cm}^{-3}$ is considered poor or droughty (Reynolds et al., 2009).

The macroporosity $\left(\mathrm{P}_{\text {MAC }}\right)\left(\mathrm{cm}^{3} \mathrm{~cm}^{-3}\right)$ is here defined as:

$$
P_{M A C}=\theta_{s}-\theta_{m}
$$

$\theta_{m}\left(\mathrm{~cm}^{3} \mathrm{~cm}^{-3}\right)$ being is the volumetric water content of the soil matrix (at $h=-10 \mathrm{~cm}$ ). It refers to the ability of the soil to quickly drain excess water and facilitate root growth. Reynolds et al. (2009) reported that the optimal values for this index should be in the range of 0.05 $0.10 \mathrm{~cm}^{3} \mathrm{~cm}^{-3}$, with $\mathrm{P}_{\text {MAC }} \leq 0.04 \mathrm{~cm}^{3} \mathrm{~cm}^{-3}$ being the lower critical limit.

The relative field capacity (RFC) (dimensionless) is defined as the ratio between field capacity and soil porosity: 
$R F C=\theta_{F C} / \theta_{s}$

Olness et al. (1998) suggested that the optimal value for $R F C$ is 0.66 . However, more recently Reynolds et al. (2009) suggested that a range of $0.6 \leq R F C \leq 0.7$ achieved the optimal balance between both air capacity and water capacity in the root zone of rain-fed agriculture soils.

Thus water limited or aeration limited soils have lower $(R F C<0.6)$ or higher $(R F C>0.7) R F C$ values, respectively. This results in low microbial production of nitrates (Reynolds et al., 2009). In other words, in rain-fed agriculture, soils with this optimal ratio are likely to have the water and air content which is most desirable for good microbial production of nitrogen more frequently and for longer periods than do soils that have larger or smaller ratios (Reynolds et al., 2002).

Dexter (2004) proposed the so-called $S$ index to evaluate the physical quality of the soil. This index is defined as the slope value of the soil water retention curve at the inflection point, when the curve is expressed as gravimetric water content.

The fundamental assumption of the $S$ theory is that the physical or structural quality of the soil is determined primarily by managementinduced structural pores, rather than texture-induced matrix pores. The structural pores consist of 3-dimensional networks of microcracks, fractures and inter-aggregate spaces (i.e. secondary structures). These are created by tillage, freeze-thaw activity, addition of amendments, drainage, crop rotation and root development (Reynolds et al., 2009).

For both temperate and tropical soils, an $\mathrm{S} \geq 0.050$ indicates very good physical or structural quality of the soil, while $0.035 \leq \mathrm{S}<0.050$ is good physical quality, $0.020 \leq S<0.035$ is poor physical quality, and $S<0.020$ is very poor or degraded physical quality (Dexter and Czyż, 2007).

Field saturated hydraulic conductivity $\left(\mathrm{K}_{f s}\right)$ is an indicator of the ability of the soil to absorb, transmit and drain water at saturated water content (Topp et al., 1997; Reynolds et al., 2008).

The $\mathrm{K}_{f s}$ value has also been used extensively as a critical parameter for indicating changes in structural quality of the soil due to changes in the crops and/or land management practices (Ankeny et al., 1990).

However, $\mathrm{K}_{f s}$ is highly sensitive to changes in pore size, roughness, tortuosity, and connectivity (Hillel, 1998) and may, therefore, be greatly over-estimated, due to the preferential flow in the extensive wormholes, root channels and shrinkage cracks (Reynolds et al., 2008). Overestimations can also generally be expected when hydraulic conductivity is determined in the laboratory on undisturbed soil cores, with differences within a factor of five (Bagarello et al., 2007), or with differences of one or more orders of magnitude greater than those measured in the field (Basile et al., 2006).

In agreement with the references in the literature (Reynolds et al., 2008 ), we considered optimal values of $\mathrm{K}_{f s}$ as being within the range $43.2-432 \mathrm{~cm} \mathrm{~d}^{-1}$. This interval may be considered ideal for agriculture soils as it promotes rapid infiltration and redistribution of crop-available water required, as well as reducing surface runoff and soil erosion, and encouraging rapid drainage of excess soil water. However, a rea- sonable upper critical limit of $\mathrm{K}_{f s}=864 \mathrm{~cm} \mathrm{~d}^{-1}$ can be considered for droughty soils, such as soils with coarse texture or excessive cracks and biopores (Topp et al., 1997), with a lower critical limit of $\mathrm{K}_{f s}<8.6 \mathrm{~cm}$ $\mathrm{d}^{-1}$ (Reynolds et al., 2007).

Two fundamental assumptions are implicit in the capacity based indicators (i.e. $\rho_{b}, A C, P_{M A C}, P A W C, R F C, S$ ) of soil physical quality: i) it is assumed that the soil is rigid or with no appreciable shrinking or swelling behaviour, and the pore volume and size distribution relationships are not affected by the variations in soil water content; ii) the socalled optimal ranges and critical limits of the capacity-based indicators are sufficiently general to be applied to a wide range of agricultural soils and climates (Reynolds et al., 2009).

The equivalent pore size distribution functions, $S_{\mathrm{v}}(h)$, may be defined as the slope of the water release curve, expressed as volumetric water content $\theta_{v}\left(\mathrm{~cm}^{3} \mathrm{~cm}^{-3}\right)$ versus $\ln (h)$, and plotted against equivalent pore diameter $d_{e}(\mu \mathrm{m})$ on a $\log _{10}$ scale. The parameter $d_{e}$ may be determined by using the capillary rise equation $\left(\mathrm{d}_{\mathrm{e}} \approx 2980 / h ; h(\mathrm{~cm})>0\right)$, and a normalised equivalent pore size distribution function, $\mathrm{S}^{*}(h)$, can be defined by dividing $\mathrm{S}_{\mathrm{v}}(h)$ by $\mathrm{S}_{\mathrm{v}}$, to obtain the following equation (Reynolds et al., 2009):

$$
S^{*}(h)=\frac{S_{v}(h)}{S_{v i}}=\frac{m(\alpha h)^{*}\left[1+m^{\prime}\right]^{m+1)}}{\left[1+(\alpha h)^{n}\right]^{m+1)}} ; 0 \leq \mathrm{S}^{*}(\mathrm{~h}) \leq 1
$$

where:

$S_{v i}$ is the slope of the water release curve, expressed as volumetric water content, at inflection point.

Moreover, if one assumes that the soil is rigid (i.e. no appreciable shrinkage-swelling behaviour), and assuming a constant $\rho_{b}$ value throughout the tension head range of the $\theta(h)$, and given that, by definition, $\theta_{\mathrm{v}}$ is equal to the product of $\rho_{b}$ and gravimetric soil water content $\left(\theta_{g}\right)$, then:

$$
S^{*}(h)=\frac{S_{v}(h)}{S_{v i}}=\frac{S_{g}(h)}{S_{g i}}
$$

In other words, $S^{*}(h)$ is independent of $\rho_{b}$ and porosity, and, therefore, provides a means for comparing pore volume distributions among different porous materials. In addition, Eq. (7) defines the links between $\mathrm{S}^{*}(h), \mathrm{S}_{\mathrm{vi}}$ and the Dexter $\mathrm{S}$-value, $\mathrm{S}_{g i \text {. }}$

The location [modal $\left(\mathrm{d}_{\text {mod }}\right)$, median $\left(\mathrm{d}_{\text {med }}\right)$ and mean $\left(\mathrm{d}_{\mathrm{m}}\right)$ pore diameter] and the shape [standard deviation (SD), skewness (Sk), and kurtosis $(\mathrm{Ku})]$ of the pore volume distribution curve, linked to the water retention curve, were calculated according to the relationships proposed by Reynolds et al. (2009), while the optimal range is shown in Table 1.

\section{Experimental site}

The study was carried out at Bitetto, near Bari, southern Italy, $\left(41^{\circ}\right.$

Table 1. Location and shape parameters for equivalent pore size distributions of both treatments considered for weed control, with indi-

\begin{tabular}{|c|c|c|c|c|c|c|}
\hline \multirow[t]{2}{*}{ Treatment } & \multicolumn{3}{|c|}{ Location parameters } & \multicolumn{3}{|c|}{ Shape parameters } \\
\hline & $\mathbf{d}_{\bmod }(\mu \mathrm{m})$ & $\mathbf{d}_{\text {med }}(\mu \mathrm{m})$ & $\mathrm{d}_{\mathrm{m}}(\mu \mathrm{m})$ & SD ( - ) & Sk ( - ) & $\mathrm{Ku}(-)$ \\
\hline No-tillage & 73 & 6 & 2 & 207 & -0.64 & 1.14 \\
\hline Surface tillage & 205 & 20 & 7 & 172 & -0.64 & 1.14 \\
\hline Optimal range & $60-140$ & $3-7$ & $0.7-2$ & $400-1000$ & -0.43 to -0.41 & $1.13-1.14$ \\
\hline
\end{tabular}
cation of optimal values.

$\mathrm{d}_{\text {mod }}, \mathrm{d}_{\text {med }}, \mathrm{d}_{\mathrm{m}}$ modal, median and geometric mean equivalent pore diameters, respectively; SD, standard deviation; Sk, skewness; Ku, kurtosis. 
02 ' latitude $\mathrm{N}, 16^{\circ} 44^{\prime}$ longitude $\mathrm{E}$, approx. $126 \mathrm{~m}$ asl), at the Experimental Farm of the unit of the Agricultural Research Centre specialising in research into cultivation in hot-dry climates (Consiglio per la Ricerca e la Sperimentazione in Agricoltura, Unità di ricerca per $i$ Sistemi Colturali degli Ambienti caldo-aridi, CRA-SCA). The average precipitation and temperatures recorded at the weather station of the experimental farm during the 20-year period from 1992 to 2012 , were $455 \mathrm{~mm}$ and $16.2^{\circ} \mathrm{C}$, respectively.

The experimental plots are situated in a zone of the Experimental Farm where the soil is deeper than the average (Ap horizon reaches up to $30 \mathrm{~cm}$ ). The surface layer of the soil (the first $30 \mathrm{~cm}$ ) consists of $42.2 \%$ clay, $28.2 \%$ silt and $29.6 \%$ sand, with a mean organic carbon content of $26.8 \mathrm{~g} \mathrm{~kg}^{-1}$. According to the USDA classification (Gee and Or, 2002), the soil texture was clay. A pedological characterization near the experimental plots (about $20 \mathrm{~m}$ away) classified the soil profile as Alfisol-Lithic Haploxeralf (SSS-USDA-NRCS, 2003), characterised by few fine pores in the Ap horizon $(0-8 \mathrm{~cm})$, and common fine and medium pores in the Bt horizon $(8-20 \mathrm{~cm})$. The sub-soil (depths greater than $20-30 \mathrm{~cm}$ ) mostly consists of fissured rock. This enables the almond rooting system to reach the deeper layers.

The long-term research used in this study started in 1977. Its main objective was to assess the different tillage and weed control systems for almond tree (Prunus amygdalus, Batsch) cultivation.

We selected two plots ( $21 \mathrm{~m}$ by $7 \mathrm{~m}$ ) from among the three systems of tillage and soil management investigated in this long-term research project. They were farmed with surface tillage (ST), consisting of disc ploughing or five-share ploughing at a depth of $20 \mathrm{~cm}$ and a rotary plough at a depth of $10 \mathrm{~cm}$, and with NT with pre-emergence chemical controls.

More details about the experimental design, tillage options and weed control methods and their corresponding combinations can be found in De Giorgio and Lamascese (2005).

\section{Soil sampling and measurements}

The experimental procedure consisted of a combination of both laboratory and field measurements, This was applied to obtain estimates of the physical quality of the soil which could be efficiently compared to those obtained in many other similar works (Abu and Abubakar, 2013; Aparicio and Costa, 2007; Cavalieri et al., 2009; Li et al., 2011; Oicha et al., 2010; Reynolds et al., 2007; Silva et al., 2011).

In order to determine the soil water retention curve and soil $\rho_{b}$ six undisturbed soil cores were collected for each plot (NT and ST) during the summer season by gently hand-hammering stainless steel cylinders (height $5 \mathrm{~cm}$, diameter $8 \mathrm{~cm}$ ) into the surface horizon of the soil, after the first few centimeters $(<3 \mathrm{~cm})$ had been removed.

In detail, desorption water retention data were obtained in the laboratory for each undisturbed soil core using a Buchner funnel apparatus (Figure 1) for pressure head values $h=-5,-10,-20,-40,-70,-100$ and $130 \mathrm{~cm}$ (Burke et al., 1986). Shortly afterwards, each soil sample was dried using the Tempe pressure cell (Soil Moisture Equipment Corp., Goleta, CA, USA) (Figure 1) and applying a pre-determined sequence of pressure head values $(h=-150,-200,-300,-400,-500,-650,-800$ and $950 \mathrm{~cm}$ ). The volumes drained during the drying process were logged using a CR10X Campbell Scientific Inc. data logger. After drying, a visual assessment of gravel content was carried out, but this fraction was always considered negligible. We also used a pressure plate apparatus (Dane and Hopmans, 2002) to determine the soil water content corresponding to $h=-3060$ and $-15,300 \mathrm{~cm}$ (Figure 1) for the re-packed soil cores.

The infiltration experiments were carried out in conjunction with the soil sampling in both plots, ST and NT, approximately three months after last tillage. Six to 9 replicates of the infiltration experiment were carried out for each plot at randomly selected locations using a tension infiltrometer (TI) (Soil Measurement System, Tucson, AZ, USA). This consists of a separate water supply and base-plate units with a $20 \mathrm{~cm}$ diameter disc (Figure 1). At each location, the soil surface was carefully levelled and smoothed before each experiment, and attempts were made to prevent infiltration surface smearing. When necessary, the plants were cut at their base with scissors while the roots remained in the soil. A spirit level was used to ensure that the disc and the reservoir base were always at the same height (zero relative distance), so that the head between the bubbling outlet at the bottom of the water supply tube and the disc membrane was constant. A retaining ring (diameter $24 \mathrm{~cm}$ ) was placed on the soil surface, and a $1 \mathrm{~cm}$ thick dry inert sand contact layer was prepared. The pressure heads set at the infiltrometer membrane were corrected to take into account the thickness of the contact material layer (Reynolds and Zebchuk, 1996). A dry-to-wet sequence of six potentials $(h=-15,-10,-6,-4,-2$ and $0 \mathrm{~cm})$ was adopted to minimise the effects of hysteresis on soil hydraulic conductivity measured in the field with the TI (Bagarello et al., 2005, 2007). Visual readings of the water level in the supply tube of the infiltrometer were taken at 0.5-2 min intervals. More details about the experimental procedure used can be found in Bagarello et al. (2005). The infiltration runs were completed within two days in order to exclude any temporal variability effect due to the different initial water content of the soil.

\section{Data analysis}

The indicators of the physical quality of the soil were calculated for each soil sample. To be precise, the $\theta(h)$ values were fitted using the RETC code (van Genuchten et al., 1991), and the water retention function was described using the van Genuchten (1980) model. This theoretical function was then used to estimate $\mathrm{P}_{\mathrm{MAC}}, \mathrm{AC}, \mathrm{RFC}$ and PAWC. Assuming the studied soil to be rigid (laboratory experiments revealed no appreciable shrinking or swelling), a value for the $S$ index was obtained according to the procedure proposed by Dexter (2004), turn-

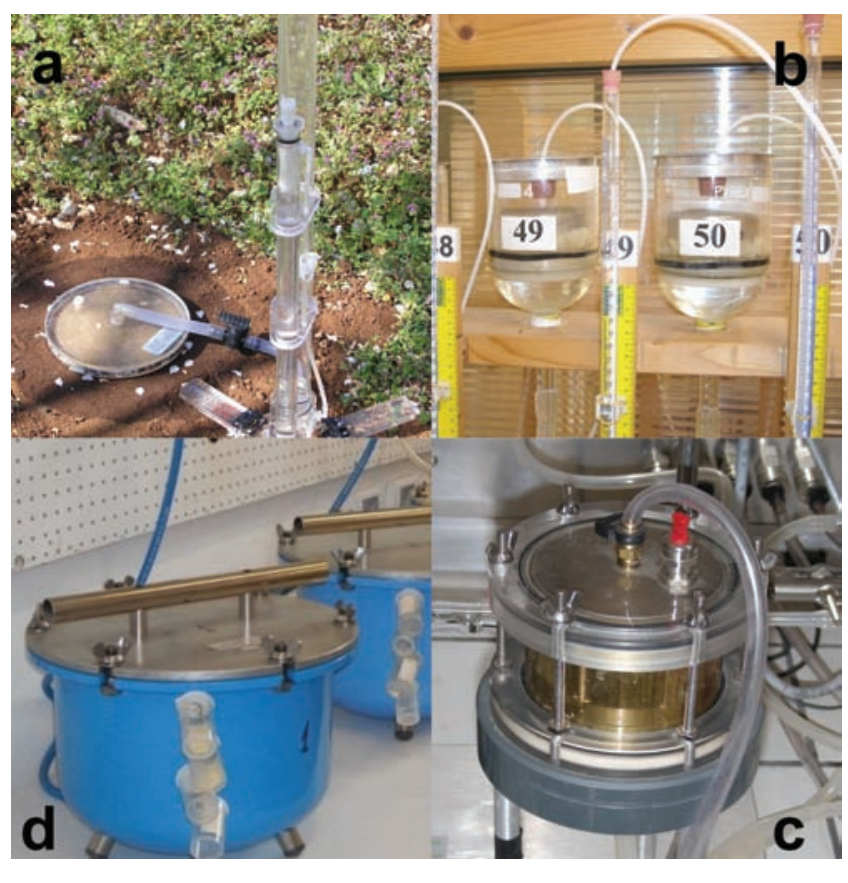

Figure 1. Tension infiltrometer (A), Buchner funnel apparatus (B), temperature cell (C) and pressure plate apparatus (D). 
ing the volumetric water content into gravimetric water content using the corresponding measurements of $\rho_{b}$.

Pore volume distribution functions and water release curves were calculated using the procedure suggested by Reynolds et al. (2009) to obtain the corresponding location $\left(\mathrm{d}_{\mathrm{mod}}, \mathrm{d}_{\mathrm{med}}, \mathrm{d}_{\mathrm{m}}\right)$ and shape (SD, Sk, $\mathrm{Ku})$ parameters for each soil sample.

Soil hydraulic conductivity (K) corresponding to each imposed $h$ value, was calculated by using the simultaneous equations method (Ankeny et al., 1991; Castellini and Ventrella, 2012). Many papers confirm this to be a reliable method of estimatation (e.g. Bagarello et al.,
2010). Two estimates of K were obtained for each intermediate $h$ value of the applied sequence. In this case, the best estimate of $\mathrm{K}$ was obtained as the arithmetic mean of the available estimates (Bagarello et $a l ., 2010)$. Field saturated hydraulic conductivity, corresponding to $h=0$, will be identified as $\mathrm{K}_{f s}$.

Mean values and the associated coefficients of variation (CVs) were calculated for each indicator of the physical quality of the soil. To be more precise, $\rho_{b}, \mathrm{P}_{\text {MAC }}, \mathrm{AC}, \mathrm{RFC}, \mathrm{PAWC}, \mathrm{S}, \mathrm{d}_{\mathrm{mod}}, \mathrm{d}_{\text {med }}$, were all assumed to be normally distributed, as is common for these variables (Reynolds et al., 2009), and the arithmetic mean and the associated CV value were
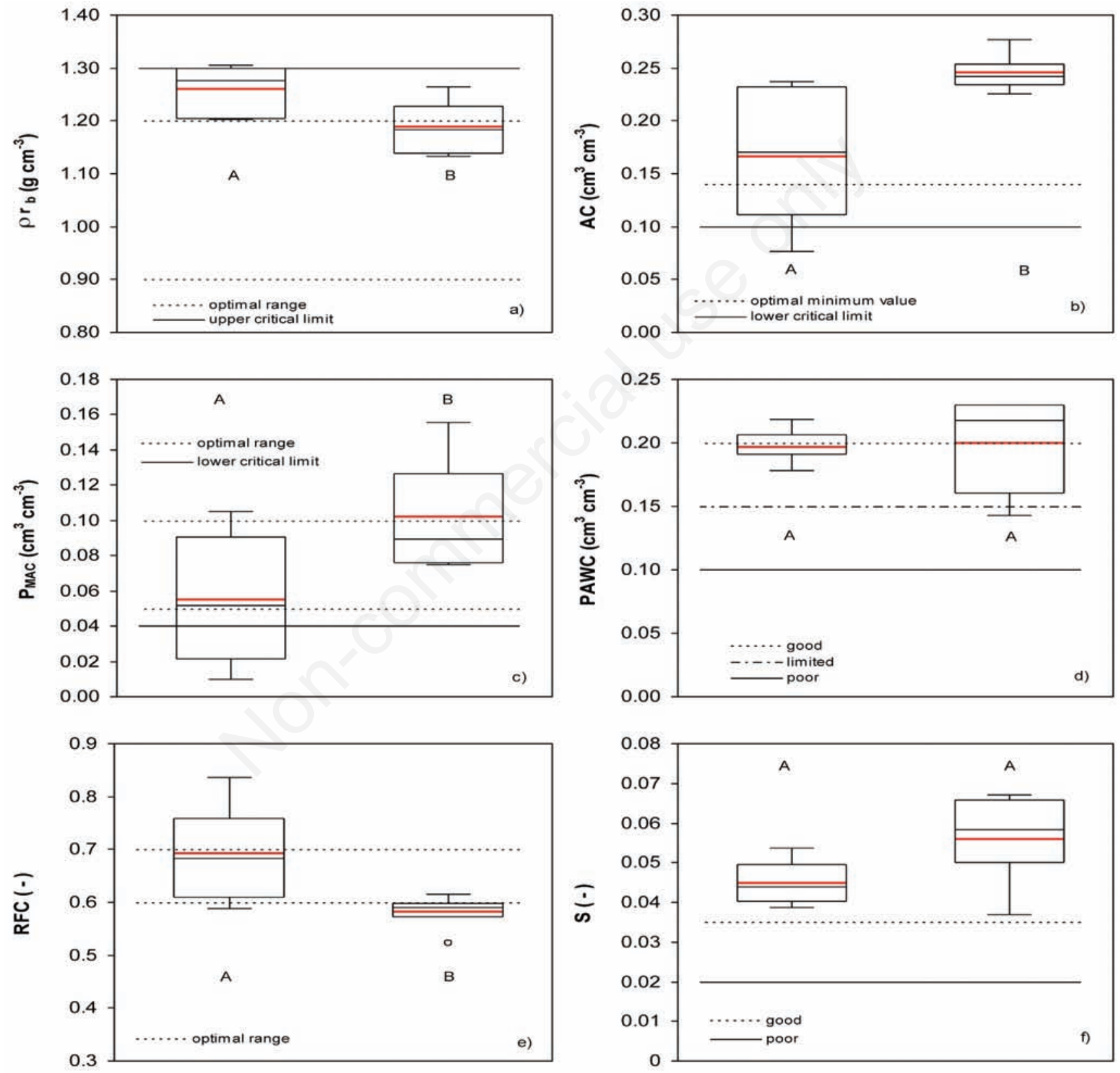

Figure 2. Comparison between no-tillage (left-hand box) and surface tillage (right-hand box) in terms of bulk density (A), air capacity (B), macroporosity (C), plant available water capacity (D), relative field capacity (E) and S index (F). Lines show proposed optimal/critical values. Mean values (lines in red-bold type within each box) with the same letter are not significantly different by Student's $t$-test $(\mathbf{P}=0.05)$. 
calculated. The other data $\left(\mathrm{d}_{\mathrm{m}}, \mathrm{SD}, \mathrm{Sk}, \mathrm{Ku}\right.$ and $\left.\mathrm{K}_{f s}\right)$ were assumed to be In-distributed (Reynolds et al., 2009), and the geometric mean and the associated CV were determined (Lee et al., 1985).

Each data set was summarized by a box plot in order to provide a visual presentation of the degree of the dispersion and skewness in the data (minimum, $1^{\text {st }}, 2^{\text {nd }}$ and $3^{\text {rd }}$ quartile, mean, maximum) and to identify extreme observations (outliers, equal to 1.5 times interquartile range). For each indicator of the physical quality of the soil, the statistical differences between NT and ST were evaluated using Student's ttest $(\mathrm{P}=0.05)$.

\section{Results and discussion}

The comparison of the capacitive indicators of the physical quality of the soil is reported in Figure 2. As expected, the mean values of soil $\rho_{b}$ observed in the NT plot were significantly higher than those in the ST plot, with differences that, at most, were equal to a factor (ratio between mean values) of 1.1. The associated coefficients of variation were, however, similar for the two treatments, with a factor (ratio between coefficients of variation) of 1.2 (Figure 2A). Mean values of $\rho_{b}$ were within the optimal range $\left(0.9 \leq \rho_{b} \leq 1.2 \mathrm{~g} \mathrm{~cm}^{-3}\right)$ only for the ST treatment (Olness et al., 1998; Reynolds et al., 2009). These are the values recommended for good root development and maximum crop production. NT had near optimal $\rho_{b}$ values (Figure 2A). However, even though the observed $\rho_{b}$ values in the NT plot (both mean and extreme values) were within the range that might cause loss of yield due to inadequate soil aeration $\left(\rho_{b} \approx 1.25-1.30 \mathrm{~g} \mathrm{~cm}^{-3}\right)$, they can probably be considered optimal for orchards, and especially for almond trees, which have an extremely vigorous root system. $\rho_{b}$ may also be considered to be a relatively significant predictor of dynamic soil properties when there are no cracks and, thus, there is no preferential flow. In this case, a decrease in the saturated hydraulic conductivity as $\rho_{b}$ increases is to be expected (Blanco-Canqui et al., 2004). As a result, the values for AC and macroporosity, $\mathrm{P}_{\mathrm{MAC}}$, were significantly higher in the ST plot by a factor of 1.5 and 1.9 , respectively (Figure $2 \mathrm{~B}$ and $\mathrm{C}$ ). In agreement with the findings reported in the literature, we always found optimal air capacity conditions $\left(\mathrm{AC}>0.14 \mathrm{~cm}^{3} \mathrm{~cm}^{-3}\right.$ ). These are recommended for minimum susceptibility to crop damage or yield-reducing aeration

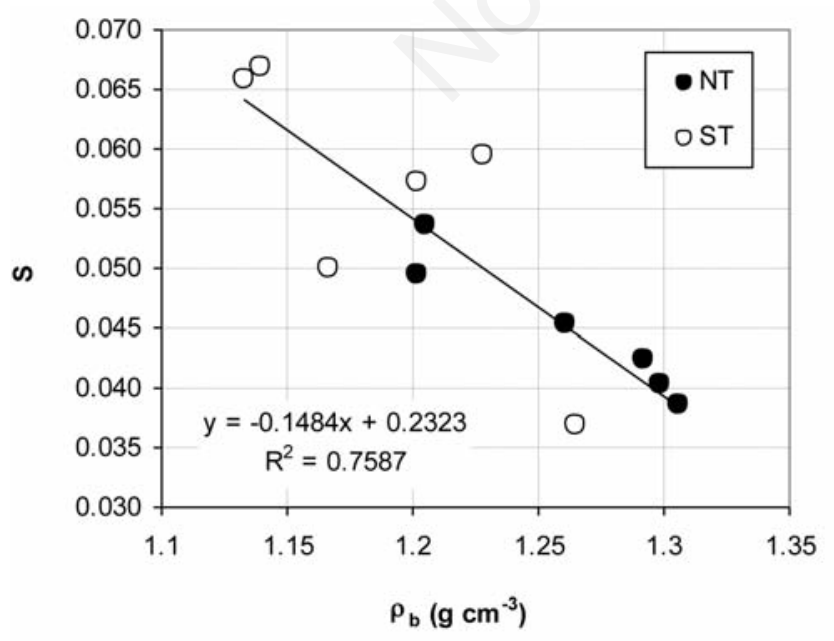

Figure 3. Linear regression between $S$ index and soil bulk density $\left(\rho_{\mathrm{b}}\right)$, with indication of different points corresponding to both no-tillage (NT) and surface tillage (ST) treatments.
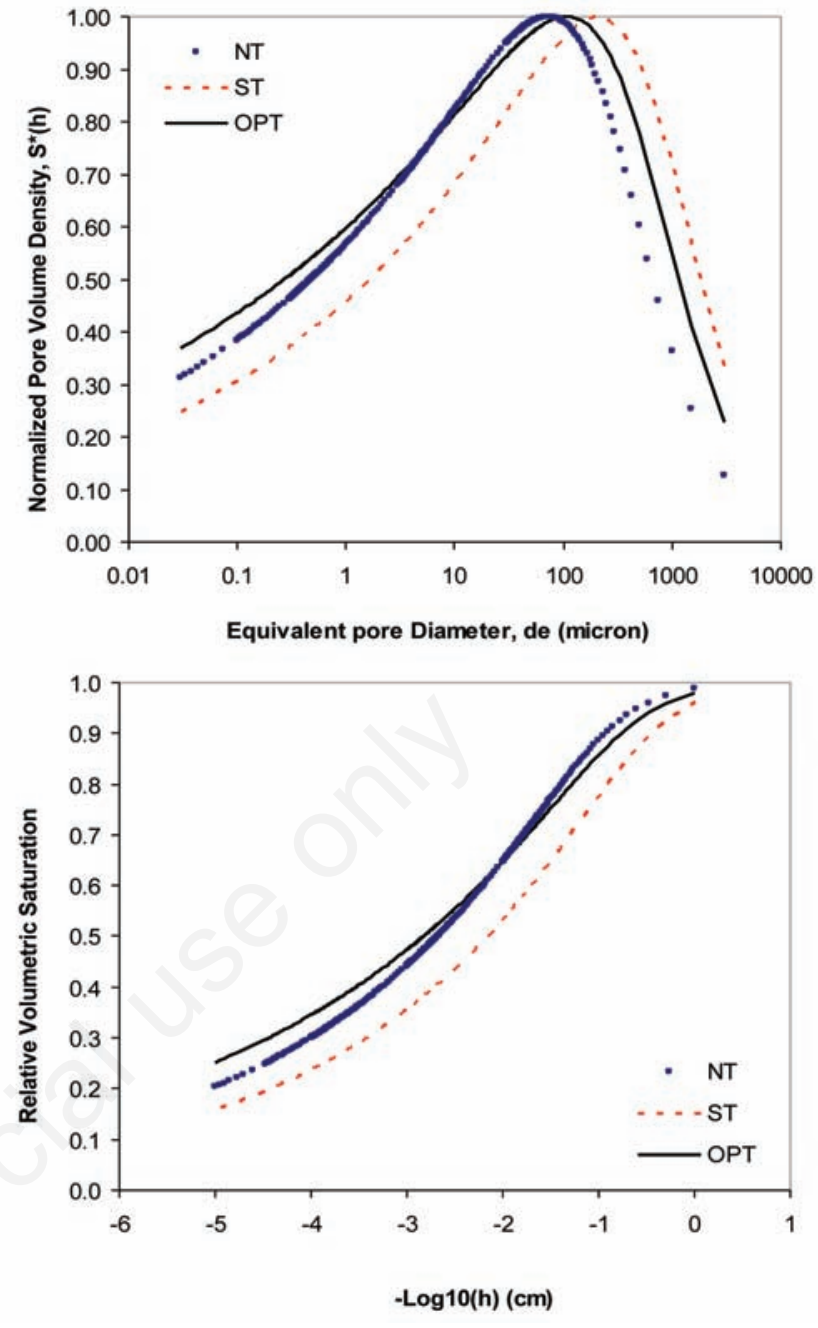

Figure 4. Pore volume distributions and water release curves for both no-tillage (NT) and surface tillage (ST) compared to the reference curve (OPT).

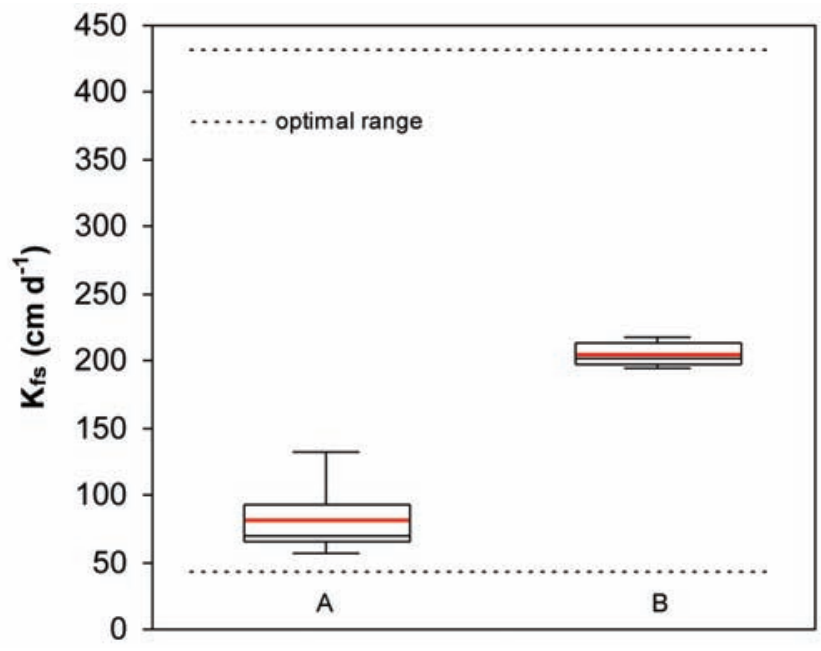

Figure 5. Comparison between no-tillage (left) and surface tillage (right) in terms of field saturated hydraulic conductivity. Mean values (lines in red-bold type within each box) with different letters are significantly different by Student's $t$-test $(\mathbf{P}=\mathbf{0 . 0 5})$. 
deficits in the root zone. Macroporosity values were also optimal $\left(0.05 \leq \mathrm{P}_{\mathrm{MAC}} \leq 0.10 \mathrm{~cm}^{3} \mathrm{~cm}^{-3}\right)$. These results suggest that both tillage options provide adequate conditions to quickly drain excess water and facilitate root proliferation (Figure $2 \mathrm{~B}$ and $\mathrm{C}$ ). However, as expected, the results for NT treatment were more variable $\left(\mathrm{CV}=0.70\right.$ for $\left.\mathrm{P}_{\mathrm{MAC}}\right)$ than for ST, with differences equal to a factor of 5.5 or 2.2, respectively, for AC and $\mathrm{P}_{\mathrm{MAC}}$. This confirms the relatively higher levels of heterogeneity of undisturbed soils. PAWC were similar between NT and ST treatments and differences were without statistical significance (Figure 2D). For this indicator of the physical quality of the soil, we found good $\left(0.15 \leq \mathrm{PAWC}<0.20 \mathrm{~cm}^{3} \mathrm{~cm}^{-3}\right.$ ) or ideal $\left(\mathrm{PAWC} \geq 0.20 \mathrm{~cm}^{3}\right.$ $\mathrm{cm}^{-3}$ ) values for maximum root growth and functions (Reynolds et al., 2009) with CV differences that were 2-3 times higher for the ST plot.

An optimal balance between root-zone soil water capacity and soil AC $(0.6 \leq \mathrm{RFC} \leq 0.7)$ was found only for no-tilled soil, while ST showed near optimal values (Olness et al., 1998). To be precise, the mean values of RFC detected in no-tilled soil were 1.2 times higher than those measured in tilled soil, with differences between the corresponding CVs equal to a factor of 2.5 (Figure 2E). A Student's t-test showed these discrepancies were statistically significant. In other words, both treatments were, in practice, within the optimal range of the relative field capacity to provide the ideal proportions of soil/water and soil/air for producing maximum soil microbial activity, regardless of soil texture and $\rho_{b}$. However, relative field capacity values lower than 0.6 , such as those measured in tilled soil, reduce microbial production of nitrates due to insufficient soil water (Reynolds et al., 2009). Therefore, since potentially limiting conditions were recognised in the sampling date of the ST plot (about 3 months after the last tillage), it is reasonable to assume that there were insufficient relative field capacity values (water limited) immediately after tillage.

The overall good physical quality associated with the clay soil, for both NT and ST, was confirmed by the $\mathrm{S}$ index, which was always over 0.035 , corresponding to conditions of good physical quality (Dexter and Czyż, 2007). In detail, mean values for physical quality of the soil, obtained for both treatments from Dexter's index, were similar (differences equal, at most, to a factor of 1.2) and not statistically different by Student's t-test (Figure 2F).

According to Dexter (2004), the S index decreases with increasing $\rho_{b}$ (Figure 3), as widely reported in the literature and as also reported by Dexter and Czyż (2007), Cavalieri et al. (2009), and Silva et al. (2011). However, given that the $S$ index is obtained from the water retention curve, it is mainly related to the pore-size distribution. This is greatly affected by soil management (such as tillage) and by soil compaction (such as raindrop effects or soil sampling). In other words, since no-tilled soil always showed optimal physical quality of the soil, with the exception of $\rho_{b}$, which was near optimal, it is plausible to hypothesise that the soil compacted slightly during sampling, especially for relatively larger pores. This reduced the macropore volume with a consequent alteration in the equivalent pore size distribution.

The location and shape parameters, and corresponding pore volume distributions and release curves, are reported in Table 1 and Figure 4, respectively. According to the results obtained from the capacitive indicators, the physical quality of the no-tilled soil was better than that of the ST, with location parameters of the soil pore volume distribution, i.e. $\mathrm{d}_{\mathrm{med}}, \mathrm{d}_{\mathrm{mod}}$ and $\mathrm{d}_{\mathrm{m}}$ (Table 1), within the optimal range (Reynolds et al., 2009). SD that takes into account the range in pore diameters was always outside the optimal range suggested by Reynolds et al. (2009) for both the treatments, suggesting a relatively low level of heterogeneity in pore diameters. However, lower values for SD were observed for tilled (ST) than no-tilled soil, thus confirming that even only surface soil tillage may change the equivalent pore size distribution.

Negative and non-optimal values for Sk were observed in both cases, with small equivalent pore diameters being prevalent rather than those expected from a lognormal distribution $(\mathrm{Sk}=-0.64)$, whereas positive and optimal values of $\mathrm{Ku}$ were detected for both treatments, showing a leptokurtic distribution $(\mathrm{Ku}=1.14)$, higher in the centre and tailing off more at the extremes than the lognormal curve (Reynolds et al., 2009).

The normalised pore volume distributions for the ST plot also showed lower densities of small pores and relatively higher densities of large pores than the optimal distribution (Reynolds et al., 2009), and the normalised release curves always showed smaller degrees of saturation than the optimal one (Figure 4). Conversely, the NT plot had near optimal pore volume distribution, up to the modal diameter (corresponding to the distribution peak), while there were lower densities of larger pores, probably due to compaction during soil sampling. The soil retention characteristics of NT soil also almost coincided with those optimal characteristics, suggesting that conservative management of orchards, with NT wherever possible, is desirable.

The estimates of physical quality obtained from the water retention curve unanimously led us to classify the NT treatment as optimal but similar results were also obtained for field saturated hydraulic conductivity, $\mathrm{K}_{f s}$ (Figure 5). Mean values of $\mathrm{K}_{f s}$ were always within the optimal range proposed by Reynolds et al. (2007) for agricultural soils, ranging from 81 to $204 \mathrm{~cm} \mathrm{~d}^{-1}$ (Figure 5). This determined an infiltration and deep drainage rate that was not too quick (and thus allowed adequate water adsorption into the soil matrix) nor too slow (and thus did not cause reduced traffic or excessive ponding or damage to the crop due to the root zone becoming waterlogged).

The observed differences in unsaturated hydraulic conductivity $(-2 \leq h \leq-15 \mathrm{~cm})$ were always significant, with discrepancies between the mean values of NT and ST which were very similar to those obtained at saturation (ST $>$ NT) and equal, at most, to a factor of 3.4. However, these findings were expected because the results for soil $\rho_{b}$ were consistent for the two treatments $(\mathrm{ST}<\mathrm{NT})$.

Finally, it is worth noting that the $\mathrm{K}_{f s}$ of NT was relatively more variable than that of $\mathrm{ST}\left(\mathrm{CV}_{\mathrm{NT}} / \mathrm{CV}_{\mathrm{ST}}\right.$ equal to a factor 8$)$. This result is probably linked to the fact that preferential flow occurred through the mesomacropore system in the NT plot. Distribution of these macrospores is generally more uneven. By contrast, tillage reduced the heterogeneity of the soil in the ST plot, breaking up the continuity, interconnections and arrangement of its pore system, and determining the same probability of sampling finding surface meso-macropores.

\section{Conclusions}

The main objective of this work was to assess the physical quality of the soil of an almond orchard where different soil tillage systems and weed control methods were used. These were no-tillage with chemical control and surface tillage. Indicators of the physical quality of the soil were used to compare the tillage-induced changes, following the guidelines laid out in the literature.

After thirty years of no-tillage, both the $\rho_{b}$ and the capacitive indicators of the physical quality (AC, $\mathrm{P}_{\mathrm{MAC}}$, PAWC, RFC), obtained from the water retention curve, unanimously classified the quality of the studied soil as good. The overall good physical quality of the soil associated with both treatments was confirmed by the $\mathrm{S}$ index, which always had mean values over 0.035 . This corresponds to good physical quality of the soil. Moreover, with the NT treatment there were optimal values for field saturated hydraulic conductivity, which promotes rapid infiltration and redistribution along the soil profile.

Our findings suggest that the equivalent pore size distribution functions may be used to assess the physical quality of the soil, in conjunc- 
tion with both capacitive indicators and measurements of the hydraulic conductivity. They provided detailed analysis of the physical quality of the soil and useful information about the rearrangement of soil particles and aggregates. They, therefore, improved our understanding of the relationships between capacitive indicators of physical quality, of equivalent pore size distributions and of the dynamic properties of the soil. Following the existing guidelines for evaluating the physical quality of the soil, and considering simultaneously all the thirteen indicators used, good physical quality was detected for $77 \%$ of NT and $46 \%$ of ST. These results support previous studies carried out on the same experimental plots (De Giorgio and Lamascese, 2005). No-tillage treatment with chemical weed control resulted in greater trunk growth and fruit yield.

The optimal intervals proposed in the literature may not be applicable for all soils or for a specific field site, because they are only general guidelines and are obtained from a wide range of soil types.

The experimental methods used in this research seemed to be suitable for detecting the effects of land use and thus may be used to compare different agricultural practices. However, even though the guidelines used were reasonably good for assessing the physical quality of the soil in the sampled area, further research is needed in order to obtain more realistic estimates of the physical quality of the soil on farms with high field crop production and minimum environmental degradation and to provide a more reliable assessment of the hydraulic properties of the soil. This will allow laboratory experiments to be conducted that will reproduce conditions in the field.

\section{References}

Abu ST, Abubakar IU, 2013. Evaluating the effects of tillage techniques on soil hydro-physical properties in Guinea Savanna of Nigeria. Soil Till. Res. 126:159-68.

Ankeny MD, Ahmed M, Kaspar TC, Horton R, 1991. Simple field method for determining unsaturated hydraulic conductivity. Soil Sci. Soc. Am. J. 55:467-70.

Ankeny MD, Kaspar TC, Horton, R, 1990. Characterization of tillage and traffic effects on unconfined infiltration measurements. Soil Sci. Soc. Am. J. 54:837-40.

Aparicio V, Costa JL, 2007. Soil quality indicators under continuous cropping systems in the Argentinean Pampas. Soil Till. Res. 96:15565.

Bagarello V, Baiamonte G, Castellini M, Di Prima S, Iovino M, 2013a. A comparison between the single ring pressure infiltrometer and simplified falling head techniques. Hydrol. Process [In Press].

Bagarello V, Castellini M, Iovino M, 2005. Influence of the pressure head sequence on the soil hydraulic conductivity determined with the tension infiltrometer Appl. Engine. Agric. 21:383-91.

Bagarello V, Castellini M, Iovino M, 2007. Comparison of unconfined and confined unsaturated hydraulic conductivity. Geoderma 137:394-400.

Bagarello V, Castellini M, Iovino M, Sgroi A, 2010. Testing the concentric-disk tension infiltrometer for field measurements of soil hydraulic conductivity. Geoderma 158:427-35.

Bagarello V, Castellini M, Di Prima S, Giordano G, Iovino M, 2013b. Testing a simplified approach to determine field saturated soil hydraulic conductivity. Proc. Environ. Sci. 19:599-608.

Basile A, Ciollaro G, Coppola A, 2003. Hysteresis in soil water characteristics as a key to interpreting comparisons of laboratory and field measured hydraulic properties. Water Resour. Res. 39:1355.

Basile A, Coppola A, De Mascellis R, Randazzo L, 2006. Scaling approach to deduce field unsaturated hydraulic properties and behavior from laboratory measurements on small cores. Vadose Zone J. 5:1005-16.

Blanco-Canqui H, Gantzer CJ, Anderson SH, Alberts EE, 2004. Tillage and crop influences on physical properties for an Epiaqualf. Soil Sci. Soc. Am. J. 68:567-76.

Burke W, Gabriels D, Bouma J, 1986. Soil structure assessment. Balkema, Rotterdam, The Netherlands.

Castellini M, Ventrella D, 2012. Impact of conventional and minimum tillage on soil hydraulic conductivity in typical cropping system in Southern Italy. Soil Till. Res. 124:47-56.

Cavalieri KMV, da Silva AP, Tormena CA, Leão TP, Dexter AR, Håkansson I, 2009. Long-term effects of no-tillage on dynamic soil physical properties in a Rhodic Ferrasol in Paraná, Brazil. Soil Till. Res. 103:158-64.

Dane JH, Hopmans JW, 2002. Water retention and storage: laboratory. In: J.H. Dane and G.C. Topp (eds.) Methods of soil analysis, physical methods - Part 4, 3rd ed. Soil Science Society of America, Inc., Madison WI, USA, pp 688-692.

De Giorgio D, Lamascese N, 2005. Long-term comparison among different soil tillage systems and weed control methods on almond tree growing in southern Italy. Options Méditerranéennes: Série A. 63:257-264.

Dexter AR, 2004. Soil physical quality: I. Theory, effects of soil texture, density, and organic matter, and ef ects on root growth. Geoderma. 120:201-14.

Dexter AR, Czyż EA, 2007. Applications of S-theory in the study of soil physical degradation and its consequences. Land Degrad. Develop. 18:369-81.

Gee GW, Or D, 2002. Particle-size analysis. In: J.H. Dane, G.C. Topp (eds.) Methods of soil analysis - Part 4, Physical methods, Number 5. Soil Science Society of America, Inc., Madison WI, USA, pp 25593.

Gómez JA, Giráldez JV, Pastor M, Fereres E, 1999. Effects of tillage method on soil physical properties, infiltration and yield in an olive orchard. Soil Till. Res. 52:167-75.

Hillel D, 1998. Environmental soil physics. Academic Press, San Diego, CA, USA, p 771.

Kassam A, Friedrich T, Derpsch R, Lahmar R, Mrabet R, Basch G, González-Sánchez EJ, Serra R, 2012. Conservation agriculture in the dry Mediterranean climate. Field Crop. Res. 132:7-17.

Lal R, 2000. World cropland soils as source or sink for atmospheric carbon. Adv. Agron. 71:145-91.

Lee DM, Reynolds WD, Elrick DE, Clothier BE, 1985. A comparison of three field methods for measuring saturated hydraulic conductivity. Can. J. Soil Sci. 65:563-73.

Li L, Chan KY, Chan KY, Niu Y, Li G, Oates A, Dexter A, Huang G, 2011. Soil physical qualities in an Oxic Paleustalf under different tillage and stubble management practices and application of $\mathrm{S}$ theory. Soil Till. Res. 113:82-8.

Logsdon SD, Karlen DL, 2004. Bulk density as a soil quality indicator during conversion to no-tillage. Soil Till. Res. 78:143-9.

Oicha T, Cornelis WM, Cornelis WM, Verplancke H, Nyssen J, Govaerts B , Behailu M, Haile M, Deckers J, 2010. Short-term effects of conservation agriculture on Vertisols under tef (Eragrostis tef (Zucc.) Trotter) in the northern Ethiopian highlands. Soil Till. Res. 106:294-302.

Olesen JE, Bindi M, 2002. Consequences of climate change for European agricultural productivity, land use and policy. Eur. J. Agron. 16:239-62.

Olness A, Clapp CE, Liu R, Palazzo AJ, 1998. Biosolids and their effects on soil properties. In: A. Wallace \& R.E. Terry (eds.) Handbook of soil conditioners. Marcel Dekker, New York, NY, USA, pp 141-65.

Pelegrin F, Moreno F, Martin-Aranda J, Camps M, 1990. The influence 
of tillage methods on soil physical properties and water balance for a typical crop rotation in SW Spain. Soil Till. Res. 16:345-58.

Pirastru M, Niedda M, 2010. Field monitoring and dual permeability modelling of water flow through unsaturated calcareous rocks. J. Hydrol. 392:40-53.

Pirastru M, Niedda M, 2013. Evaluation of the soil water balance in an alluvial floodplain with a shallow groundwater table. Hydrol. Sci. J. 58:898-911.

Reynolds WD, Zebchuk WD, 1996. Use of contact material in tension infiltrometer measurements. Soil Technol. 9:141-59.

Reynolds WD, Bowman BT, Drury CF, Tan CS, Lu X, 2002. Indicators of good soil physical quality: density and storage parameters. Geoderma 110:131-46.

Reynolds WD, CF Drury, Tan CS, Fox CA, Yang XM, 2009. Use of indicators and pore volume-function characteristics to quantify soil physical quality. Geoderma 152:252-63.

Reynolds WD, Drury CF, Yang XM, Fox CA, Tan CS, Zhang TQ, 2007. Land management effects on the near-surface physical quality of a clay loam soil. Soil Till. Res. 96:316-30.

Reynolds WD, Drury CF, Yang XM, Tan CS, 2008. Optimal soil physical quality inferred through structural regression and parameter interactions. Geoderma 146:466-74.

Shahab H, Emami H, Karimi A, 2013. Pore size distribution as a soil physical quality index for agricultural and pasture soils in northeastern Iran. Pedosphere 23:312-20.

Shaver TM, Peterson GA, Ahuja LR, Westfall DG, Sherrod LA, Dunn G,
2002. Surface soil physical properties after twelve years of dryland no-till management. Soil Sci. Soc. Am. J. 66:1296-303.

Silva GL, Lima HV, Campanha MM, Gilkes RJ, Oliveira TS, 2011. Soil physical quality of Luvisols under agroforestry, natural vegetation and conventional crop management systems in the Brazilian semiarid region. Geoderma 167-168:61-70.

SSS-USDA-NRCS, 2003. Key to soil taxonomy, 9th ed. USDA, Washington, DC, USA.

Strudley MW, Green TR, Ascough JC, 2008. Tillage effects on soil hydraulic properties in space and time: state of the science. Soil Till. Res. 99:4-48.

Tebrügge F, Düring RA, 1999. Reducing tillage intensity: a review of results from a long-term study in Germany. Soil Till. Res. 53:15-28.

Topp GC, Reynolds WD, Cook FJ, Kirby JM, Carter MR, 1997. Physical attributes of soil quality. In: E.G. Gregorich and M.R. Carter (ed.) Soil quality for crop production and ecosystem health. Dev. Soil Sci. 25. Elsevier, New York, NY, USA, pp 21-58.

Unger PW, Fulton LJ, 1990. Conventional- and no-tillage effects on upper root zone soil conditions. Soil Till. Res. 16:337-44.

van Genuchten MT, 1980. A closed form equation for predicting the hydraulic conductivity of unsaturated soils. Soil Sci. Soc. Am. J. 44:892-8.

van Genuchten MT, Leij FJ, Yates SR, 1991. The RETC code for quantifying the hydraulic functions of unsaturated soils. Salinity Laboratory, Riverside, CA, USA. 